\title{
Effect of dietary copper source on response to coliform mastitis in dairy cows
}

\author{
R. W. Scaletti ${ }^{1}$ and R. J. Harmon† \\ ${ }^{*}$ Alltech Center for Animal Nutrigenomics and Applied Animal Nutrition, Alltech Inc., Nicholasville, KY 40356-9765 \\ †Department of Animal and Food Sciences, University of Kentucky, Lexington 40546-0215
}

\begin{abstract}
The effect of organic or inorganic dietary $\mathrm{Cu}$ on Escherichia coli mastitis was investigated in first-lactation heifers. Twenty-eight primigravid Holstein heifers were assigned to 3 treatments in a completely randomized block design with 10 blocks of 3 animals grouped by expected calving date. Treatments were as follows: basal diet $[7.1 \mathrm{mg} \mathrm{Cu} / \mathrm{kg}$ of dry matter (DM); CON] and diets supplemented with $\mathrm{Cu}(10 \mathrm{mg} / \mathrm{kg}$ of $\mathrm{DM})$ as $\mathrm{Cu}$ sulfate (CUS) or as $\mathrm{Cu}$ proteinate (CUP). Treatments were fed individually from $60 \mathrm{~d}$ prepartum through 49 $\mathrm{d}$ of lactation. All heifers were marginally deficient at the onset of the experiment (liver $\mathrm{Cu}$ of $60 \mathrm{mg} / \mathrm{kg}$ ) and did not differ between groups. Mean liver $\mathrm{Cu}$ concentrations were about 3 -fold greater in CUS and CUP compared with CON at d 0,21 , and 42 of lactation. At d 34 postpartum, one pathogen-free quarter per cow was infused with Escherichia coli strain 727. Copper supplementation did not lower peak responses to challenge; however, CUP tended to offer some benefits: milk bacterial count with CUP was lower compared with CON at 24, 48, and $72 \mathrm{~h}$ and lower than CUS at 24 and $96 \mathrm{~h}$, and postchallenge milk production tended to be greater for CUP. Clinical udder score was lower at $12 \mathrm{~h}$ for CUP and CUS compared with CON, and at $144 \mathrm{~h}$ CUP had lower clinical scores compared with CUS or CON. Somatic cell count, dry matter intake, plasma $\mathrm{Cu}$, and plasma ceruloplasmin did not differ between treatments. Compared with the control diet or $\mathrm{Cu}$ sulfate supplement, supplementation with $\mathrm{Cu}$ proteinate tended to improve the clinical status of cows after live $E$. coli intramammary challenge.
\end{abstract}

Key words: dairy cow, mastitis, copper, coliform

\section{INTRODUCTION}

Sound mastitis control is critical in producing high quality milk and preserving dairy cattle health. Nutritional interventions that address essential micronutrients, such as vitamin E, selenium, zinc, and copper,

Received April 10, 2011.

Accepted October 5, 2011.

${ }^{1}$ Corresponding author: rscaletti@alltech.com have been shown effective in improving udder health and reducing SCC in milk (Smith et al., 1984, 1997; Erskine, 1993; Harmon and Torre, 1997). Copper sulfate supplementation of dairy cattle has been shown to reduce the incidence and severity of IMI in response to experimentally induced mastitis using endotoxin (Harmon et al., 1994) or live Escherichia coli (Scaletti et al., 2003) in primiparous Holstein heifers.

Supplementation of animal feed with micronutrients has traditionally relied on inorganic sources. However, in recent years research in ruminants indicates that organic forms of some micronutrients may be more biologically available. Such benefits have been demonstrated in dairy cattle for both selenium (Malbe et al., 1995; Knowles et al., 1999; Ortman and Pehrson, 1999; Malbe et al., 2003; Ceballos-Marquez et al., 2010) and zinc (Wright and Spears, 2001; Cope et al., 2009). A study by Harmon (1998) found that supplementation of heifers with organic, proteinated $\mathrm{Cu}$ (Bioplex, Alltech Inc., Nicholasville, KY), compared with $\mathrm{Cu}$ sulfate, resulted in a lower percentage of quarters infected with major pathogens. Moreover, unlike $\mathrm{Cu}$ sulfate, the Bioplex treatment was linked to increased plasma $\mathrm{Cu}$ levels without marked stimulation of ceruloplasmin $(\mathbf{C p})$, suggesting that the mechanism of $\mathrm{Cu}$ absorption and (or) transport differs between organic and inorganic forms (Harmon, 1998).

The objective of this study was to compare the effects of organic and inorganic sources of dietary $\mathrm{Cu}$ on the response of primiparous heifers to live E. coli intramammary challenge.

\section{MATERIALS AND METHODS}

This experiment was approved in advance by the Institutional Animal Care and Use Committee of the University of Kentucky and conducted in accordance with the principles and guidelines on animal care and use of the Federation of Animal Science Societies (1999).

\section{Experimental Design}

Forty-two pregnant Holstein heifers were assigned to treatments in a completely randomized block design, with animals blocked in groups of 3 by expected calv- 
ing date. Of the 42 Holstein heifers in the study, 14 were removed from the study. Seven were removed after the prepartum concentrate was determined to have supplemental $\mathrm{Cu}$ (about $100 \mathrm{mg} / \mathrm{kg}$ of $\mathrm{DM}$ ) due to an error with the commercial feed mill that supplied the concentrate. Three were removed because of retained placentas (1 CUS and 1 CUP) and uterine infections (1 CUP) postpartum. One heifer was removed for each of the following reasons: displaced abomasum after parturition (CUS), leg injury (CUP), and death (CON). The final heifer that was removed was normal (CUS), but all other heifers in her block were removed. Data were analyzed for 9 CON, 10 CUS, and 9 CUP heifers. The trial began in August 2000 and was completed in July 2002. Heifers were not fed supplemental $\mathrm{Cu}$ from about 5 mo of age until study enrollment, which created marginal liver $\mathrm{Cu}$ deficiency $(60 \mathrm{mg} / \mathrm{kg}$ of $\mathrm{DM}$; Puls, 1994). At $60 \mathrm{~d}$ before anticipated calving, heifers were assigned to dietary treatments. Treatment groups were (1) basal diet $(7.1 \mathrm{mg} / \mathrm{kg}$ of $\mathrm{DM}$ of $\mathrm{Cu}, \mathbf{C O N} ; \mathrm{n}$ $=9$ ), (2) basal diet plus $10 \mathrm{mg} / \mathrm{kg}$ of DM of $\mathrm{Cu}$ as $\mathrm{Cu}$ sulfate in a ground corn carrier individually fed as a top-dress (CUS; $\mathrm{n}=10$ ), and (3) basal diet plus 10 $\mathrm{mg} / \mathrm{kg}$ of $\mathrm{DM}$ of $\mathrm{Cu}$ as $\mathrm{Cu}$ proteinate (Bioplex $\mathrm{Cu}$; Alltech Inc.) in a ground corn carrier individually fed as a top-dress (CUP; $\mathrm{n}=9$ ). A prepartum diet was fed ad libitum from 60 to $21 \mathrm{~d}$ before anticipated parturition and consisted of corn silage and alfalfa silage (equal proportion, DM basis) and $1.8 \mathrm{~kg}$ of concentrate per day mixed with forages (Table 1). A prepartum transition diet was fed ad libitum from $21 \mathrm{~d}$ before parturition until parturition and consisted of corn silage and alfalfa silage (equal proportion, DM basis) and 3.6 $\mathrm{kg}$ of concentrate per day mixed with forages (Table 1). The postpartum diet (Table 1) was fed as a TMR and consisted of corn silage ( $25 \%$ of diet DM), alfalfa silage ( $25 \%$ of diet DM), and concentrate (50\% of diet DM). The prepartum diet met NRC (1989) requirements for all nutrients except $\mathrm{Cu}, \mathrm{Zn}$, Se, and $\mathrm{Na}$ (Table 1). Selenium was supplemented at $0.23 \mathrm{mg} / \mathrm{kg}$ of DM (NRC, 1989 requirement $0.3 \mathrm{mg} / \mathrm{kg}$ of $\mathrm{DM}$ ) to provide $2.7 \mathrm{mg}$ of Se per day. Dietary Na was $0.09 \%$ of diet DM, total dietary $\mathrm{Zn}$ was $28.5 \mathrm{mg} / \mathrm{kg}$ of DM, and total dietary $\mathrm{Cu}$ was $7.7 \mathrm{mg} / \mathrm{kg}$ of DM (NRC, 1989 requirement $0.10 \%$, $40 \mathrm{mg} / \mathrm{kg}$ of DM, and $10 \mathrm{mg} / \mathrm{kg}$ of DM, respectively). The prepartum transition diet met NRC (1989) requirements for all nutrients except $\mathrm{Cu}$ and $\mathrm{Na}$ (Table 1). Dietary $\mathrm{Na}$ was $0.09 \%$ of $\mathrm{DM}$ and dietary $\mathrm{Cu}$ was $6.7 \mathrm{mg} /$ $\mathrm{kg}$ of DM (NRC, 1989 requirement $0.10 \%$ and $10 \mathrm{mg} /$ $\mathrm{kg}$ of DM, respectively). Vitamin E was supplemented at $1,004 \mathrm{IU} / \mathrm{d}$ and supplemental Se was $3.6 \mathrm{mg} / \mathrm{d}$. The postpartum diet met NRC (1989) requirements for all nutrients except $\mathrm{Cu}$ and ADF (Table 1). Acid detergent fiber was $18.7 \%$ of $\mathrm{DM}$ and dietary $\mathrm{Cu}$ was $6.8 \mathrm{mg} / \mathrm{kg}$ of DM (NRC, 1989 requirement $>19 \%$ and $10 \mathrm{mg} / \mathrm{kg}$ of DM, respectively). Vitamin E was supplemented at 535 $\mathrm{IU} / \mathrm{d}$ and supplemental Se was $5.7 \mathrm{mg} / \mathrm{d}$ in the postpartum diet. Dietary Fe was about $460 \mathrm{mg} / \mathrm{kg}$ of DM for all diets. Experimental heifers were housed in a tiestall barn bedded with sawdust and allowed access to a dirt lot about $4 \mathrm{~h} / \mathrm{d}$. Dry matter intake was measured daily and BW obtained weekly. Heifers were moved to a box stall bedded with straw about $3 \mathrm{~d}$ before parturition and returned to the tie-stall barn about $3 \mathrm{~d}$ after parturition. After parturition, animals were milked at 0430 and $1530 \mathrm{~h}$ daily. All forages and concentrates were sampled every other week and stored at $-20^{\circ} \mathrm{C}$. The samples were compiled every 3 mo, sub-sampled, and sent to a commercial laboratory (Northeast DHIA Forage Analysis Laboratory, Ithaca, NY) for mineral and nutrient analysis by wet chemistry.

\section{Intramammary Bacterial Challenge}

Escherichia coli strain 727, originally isolated from a naturally occurring IMI, was used as the challenge pathogen. Challenge inoculum was prepared as described by Scaletti et al. (2003). One quarter of each heifer was challenged by intramammary infusion of the challenge strain $5 \mathrm{~h}$ after the morning milking and feeding. Quarters chosen for challenge were bacteriologically negative and had a geometric mean SCC of 55,000 at the time of challenge. The geometric mean of the colony-forming units for inoculum was 29 (20 to 40) suspended in Hanks' balanced salt solution. Heifers within the same block were challenged on the same day. The arithmetic mean DIM at challenge was $32 \mathrm{~d}$ (25 to $50 \mathrm{~d})$.

\section{Sample Collection and Analysis}

Liver Biopsies. At 60 and 21 d prepartum, within $3 \mathrm{~d}$ postpartum, and at 21 and $49 \mathrm{~d}$ postpartum, liver samples (average weight $0.16 \mathrm{~g}$ of dry weight) were obtained via biopsy (Erwin et al., 1956) to determine $\mathrm{Cu}$ status. After collection, samples were analyzed as previously reported (Scaletti et al., 2003). Samples were rinsed with saline and stored at $-20^{\circ} \mathrm{C}$ until analysis by atomic absorption spectrophotometry (Solaar, Thermo Jarrell Ash Corp., Franklin, MA) using the wet-ashing procedure previously reported (Scaletti et al., 2003). Dried samples were digested in $12 \mathrm{~mL}$ of concentrated nitric acid and then digested again in $10 \mathrm{~mL}$ of $30 \%$ hydrogen peroxide. Samples were dried and reconstituted in $10 \mathrm{~mL}$ of $1 \mathrm{~N}$ hydrochloric acid and analyzed for $\mathrm{Cu}$. Results were reported on a dry weight basis.

Milk and Blood Samples. Duplicate quarter foremilk samples were aseptically collected within $3 \mathrm{~d}$ of 
Table 1. Calculated nutrient composition of prepartum, prepartum transition, and postpartum diets from assayed values of feeds (DM basis) ${ }^{1}$

\begin{tabular}{|c|c|c|c|}
\hline Item & Prepartum & $\begin{array}{l}\text { Prepartum } \\
\text { transition }\end{array}$ & Postpartum \\
\hline $\mathrm{CP}, \%$ & 15.92 & 15.31 & 17.75 \\
\hline $\mathrm{ADF}, \%$ & 26.96 & 23.36 & 18.72 \\
\hline NDF, \% & 39.33 & 34.25 & 28.65 \\
\hline $\mathrm{Ca}, \%$ & 1.05 & 1.17 & 1.40 \\
\hline $\mathrm{P}, \%$ & 0.46 & 0.50 & 0.64 \\
\hline $\mathrm{Mg}, \%$ & 0.20 & 0.20 & 0.26 \\
\hline $\mathrm{K}, \%$ & 1.79 & 1.55 & 1.49 \\
\hline $\mathrm{Na}, \%$ & 0.09 & 0.09 & 0.55 \\
\hline S, $\%$ & 0.18 & 0.18 & 0.27 \\
\hline $\mathrm{Fe}, \mathrm{mg} / \mathrm{kg}$ & 467.0 & 461.2 & 443.5 \\
\hline $\mathrm{Zn}, \mathrm{mg} / \mathrm{kg}$ & 28.5 & 39.6 & 46.8 \\
\hline $\mathrm{Cu},{ }^{2} \mathrm{mg} / \mathrm{kg}$ & 7.7 & 6.7 & 6.8 \\
\hline $\mathrm{Mn}, \mathrm{mg} / \mathrm{kg}$ & 72.6 & 78.8 & 118.4 \\
\hline $\mathrm{Mo}, \mathrm{mg} / \mathrm{kg}$ & 1.0 & 1.0 & 1.0 \\
\hline $\mathrm{Se},{ }^{3} \mathrm{mg} / \mathrm{kg}$ & 0.23 & 0.37 & 0.34 \\
\hline Vitamin $\mathrm{A},{ }^{4} \mathrm{IU} / \mathrm{d}$ & 8,092 & 32,000 & 80,000 \\
\hline Vitamin $\mathrm{D},{ }^{4} \mathrm{IU} / \mathrm{d}$ & 3,197 & 6,400 & 16,000 \\
\hline Vitamin $\mathrm{E},{ }^{4} \mathrm{IU} / \mathrm{d}$ & 125 & 1,004 & 535 \\
\hline $\mathrm{NE}_{\mathrm{L}}, \mathrm{Mcal} / \mathrm{kg}$ & 1.53 & 1.61 & 1.71 \\
\hline
\end{tabular}

parturition, and on lactation d 7, 14, 21, and 49 for microbiological analysis and SCC determination to verify mammary gland health. Milk microbiological status was determined using procedures recommended by the National Mastitis Council (Harmon et al., 1990). Culture results from duplicate samples that did not match were not included in the data set. Somatic cell count was determined by commercial laboratory (Mid-South DHIA, Springfield, MO) using an electronic counter. Quarter foremilk samples (for SCC and bacteriology) were also collected $24 \mathrm{~h}$ before challenge, immediately before challenge $(0 \mathrm{~h})$, and $6,12,18,24,36,48,72$, $96,144,192$, and $240 \mathrm{~h}$ postchallenge. Jugular blood samples were also collected at these sample times by venipuncture in Vacutainers (Becton, Dickinson and Co., Franklin Lakes, NJ) containing lithium heparin (for plasma mineral analysis and Cp activity) and Vacutainers containing potassium EDTA (for hematocrit, white blood cell count, and erythrocyte sedimentation rate). Whole blood was centrifuged for $20 \mathrm{~min}$ at 1,000 $\times g$, and plasma was frozen at $-20^{\circ} \mathrm{C}$ in aliquots for later use. Thawed plasma was diluted 1:4 (vol/vol) in distilled, deionized nanopure water and analyzed using atomic absorption spectrophotometry to determine $\mathrm{Cu}, \mathrm{Fe}$, and $\mathrm{Zn}$ concentrations. Plasma $\mathrm{Cp}$ activity was measured as oxidase activity using the procedure of Schosinsky et al. (1974) which uses o-dianisidine dihydrochloride as substrate. The procedure was adapted to a microplate format that allowed the assay of samples in quadruplicate. Whole blood was used to determine white blood cell count (WBC) by an electronic cell counter (Coulter Corporation, Miami, FL); erythrocyte sedimentation rate was determined following the procedure of Sox and Liang (1986); and hematocrit was determined using a microhematocrit procedure. Colony-forming units of E. coli per milliliter and SCC were determined in quarter foremilk samples postchallenge. Colony-forming units were determined by appropriate 10-fold dilutions in PBS and surface plated in duplicate on McConkey agar plates. A 0.1-mL aliquot of undiluted milk was plated on the surface of a blood agar plate and in duplicate on the surface of McConkey agar plates. The SCC was determined as described earlier. Milk samples from 12 to $144 \mathrm{~h}$ were diluted 1:10 in PBS to obtain accurate SCC for samples that exceeded the upper limit (9.7 million cells $/ \mathrm{mL}$ ) of the electronic cell counting equipment. Raw data were expressed as $\log _{10}$ $\mathrm{cfu} / \mathrm{mL}$ and $\log _{10} \mathrm{SCC} / \mathrm{mL}$ of milk.

\section{Clinical Signs}

The clinical status of all quarters was recorded on a 5-point scale at the time quarter foremilk samples were obtained following the scale outlined by Hogan et al. (1995). The scale was as follows: $1=$ normal milk and normal quarter; $2=$ normal quarter but questionable milk; $3=$ normal quarter but abnormal milk; $4=$ swollen quarter and abnormal milk; and $5=$ swollen 
quarter, abnormal milk, and systemic signs of infection. Clots, discoloration, or a serous appearance were signs of abnormal milk. Rectal temperatures were measured immediately before challenge and each time quarter samples were collected postchallenge.

\section{Milk Production and DMI During Challenge}

Milk production was recorded from weigh jars after each milking. Milking times were 0430 and 1530 h. Daily feed intake was recorded for all heifers. Daily milk production and DMI were expressed as percentages of means for the $7 \mathrm{~d}$ before challenge following the formula used by Hogan et al. (1995). The formula used was $(\mathrm{b} / \mathrm{a} \times 100)$, where $\mathrm{a}=$ mean value for the $7 \mathrm{~d}$ before challenge, and $\mathrm{b}=$ daily value postchallenge.

\section{Statistical Analysis}

Treatment differences for bacterial counts, SCC, rectal temperatures, clinical scores, blood and liver mineral concentrations, Cp activity, white blood cell count, and DMI and milk production (as percentages of prechallenge means) were tested using the PROC MIXED procedure and protected least significant difference (SAS Institute, 1985). Models included fixed effects of treatment, block, time of sampling, and interaction of main effects. Animal within treatment was included in the model for random subject effects. Infection prevalence (percentages) data were tested using chi-squared analyses. Significance was determined at $P<0.05$, and trends were noted at $P<0.10 . \log _{10}$ transformations were done on bacterial counts, SCC, and white blood cell counts to normalize data before analysis.

\section{RESULTS AND DISCUSSION}

\section{Liver Cu}

Dietary supplementation with $\mathrm{Cu}$ at $10 \mathrm{mg} / \mathrm{kg}$ of DM from CUS or CUP for $40 \mathrm{~d}$ provided sufficient $\mathrm{Cu}$ sources to achieve adequate liver $\mathrm{Cu}$ concentration according to levels defined by Puls (1994) and Mills (1987). Liver $\mathrm{Cu}$ did not differ $(P=0.58)$ between groups before dietary treatments $60 \mathrm{~d}$ prepartum. At d 21 prepartum and at d 0, 21 and 49 postpartum liver $\mathrm{Cu}$ was greater [treatment $($ Trt $) \times$ time, $P<0.0001$; time, $P<0.0001$; Trt, $P<0.0003]$ in $\mathrm{Cu}$-supplemented groups compared with unsupplemented control heifers. Overall liver $\mathrm{Cu}$ concentrations were $64.7,174.5$, and $172.8 \mathrm{mg} / \mathrm{kg}$ of DM for CON, CUS, and CUP heifers, respectively. Differences between CUS and CUP treatments were not significant $(P=0.93)$. Liver $\mathrm{Cu} 10 \mathrm{~d}$ before intramammary challenge was $60.6 \mathrm{mg} / \mathrm{kg}$ of DM for CON heifers and 181.1 and $215.1 \mathrm{mg} / \mathrm{kg}$ of DM for CUS and CUP heifers, respectively.

\section{Experimental E. coli Challenge}

Responses of heifers to E. coli challenge were moderately influenced by supplemental $\mathrm{Cu}$ at $10 \mathrm{mg} / \mathrm{kg}$ of DM. Copper supplementation did not lower peak responses after intramammary challenge although variable benefits were observed for $\mathrm{Cu}$ supplementation. Supplementation with CUP had greater effects for some parameters compared with CON and CUS. Heifers supplemented with CUP were better able to limit E. coli growth in the mammary gland, which appeared to translate to improved clinical udder score and tendency for improved recovery to normal milk yield. Each quarter challenged developed an IMI and clinical mastitis. All quarters used for challenge were bacteriologically negative at the time of challenge with SCC that averaged 55,000 cells/mL. A review of the literature revealed limited studies investigating effects of organic and inorganic $\mathrm{Cu}$ supplementation on mastitis (Harmon, 1998) and no other studies investigating effects of organic $\mathrm{Cu}$ supplementation on experimentally induced mastitis compared with inorganic sources. Studies in ewes (Jones and Suttle, 1981), dairy steers (Boyne and Arthur, 1981; Xin et al., 1991), and dairy heifers (Harmon et al., 1994; Torre et al., 1996; Scaletti et al., 2003) have shown the role of $\mathrm{Cu}$ in immune response. Macrophages and neutrophils are important for nonspecific cellular immune functions, protecting the mammary gland against infection through the phagocytosis and killing of invading microorganisms (Craven and Williams, 1985).

\section{Bacterial Count}

Escherichia coli numbers increased dramatically in milk from the challenged quarters after infusion, approaching or exceeding $10^{4} \mathrm{cfu} / \mathrm{mL}$ in all treatments (Figure 1; Trt $\times$ time, $P<0.05$; time, $P<0.0001$; Trt, $P<0.11$ ). All challenged quarters were bacteriologically negative by culture of milk at $0 \mathrm{~h}$. Escherichia coli was first isolated from the $6 \mathrm{~h}$ sample from all treatment groups. Bacterial counts increased sharply from 6 to $12 \mathrm{~h}$, with peak numbers of $E$. coli being reached at 12 h. Peak numbers did not differ $(P=0.55)$ and were $3.92,4.43$, and $4.24 \log _{10} \mathrm{cfu} / \mathrm{mL}$ for CON, CUS, and CUP heifer groups, respectively. Heifers supplemented with CUP had lower $(P=0.02)$ bacterial counts at $24 \mathrm{~h}$ compared with CUS and CON heifers. At $48 \mathrm{~h}$, CUP heifers tended to have $(P=0.10)$ less $E$. coli in milk than CON heifers. Heifers supplemented with CUP continued to have less $(P=0.05)$ bacteria in 
milk at $72 \mathrm{~h}$ compared with CUS and CON heifers. At $96 \mathrm{~h}$, CUP heifers tended to have lower $(P=0.07)$ bacterial counts compared with CUS heifers. No other differences between treatments were observed, although bacterial numbers in CUP animals tended to remain numerically lower than those of the other 2 treatment groups throughout the remainder of the trial. Supplementation with CUP provided some benefit for the elimination of the infection, or in limiting bacterial growth, or both. Other factors not measured may have improved bacterial elimination and subsequently improved milk production recovery. Some of these factors could include modifying the environment of the gland affecting neutrophil function or affecting lactoferrin, which is an Fe-binding antibacterial protein (Anderson et al., 1985).

\section{SCC}

The SCC of milk from the infused mammary quarter was constant from 0 to $6 \mathrm{~h}$ for all treatment groups (Figure 2). No differences were observed for any of the samples (Trt $\times$ time, $P<0.76$; time, $P<0.0001$; Trt, $P<0.74)$. Beginning at $12 \mathrm{~h}, \mathrm{SCC}$ sharply increased by 20 -fold for all treatment groups and at $18 \mathrm{~h} \mathrm{SCC}$ increased more than 30-fold for all treatment groups. Peak SCC was reached at $36 \mathrm{~h}$ and was 7.84, 7.48, and $7.60 \log _{10}$ cells/mL for CON, CUS, and CUP heifers, respectively. After $36 \mathrm{~h}$, SCC gradually decreased in all 3 treatment groups until $240 \mathrm{~h}$.

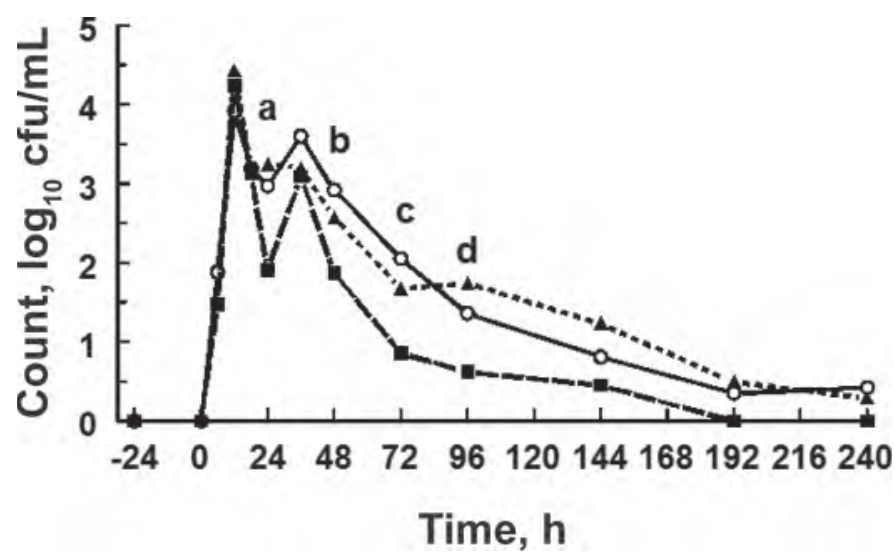

Figure 1. Least squares means Escherichia coli numbers $\left(\log _{10} \mathrm{cfu} /\right.$ $\mathrm{mL}$ ) in milk after intramammary challenge with E. coli strain 727 at $0 \mathrm{~h}$ in first-lactation heifers with $10 \mathrm{mg} / \mathrm{kg}$ of DM supplemental dietary copper as $\mathrm{Cu}$ sulfate $(\mathbf{\Lambda} ; \mathrm{n}=10)$ or $\mathrm{Cu}$ proteinate $(\mathbf{\square} ; \mathrm{n}=9)$ and unsupplemented control heifers $(\mathrm{O} ; \mathrm{n}=9)$. Pooled SEM $=0.33$. Treatment $\times$ time, $P<0.05 .{ }^{a} P=0.02$, CUP versus CUS and CON ${ }^{\mathrm{b}} P=0.10$, CUP versus $\mathrm{CON} ;{ }^{\mathrm{c}} P=0.05$, CUP versus CUS and CON; ${ }^{\mathrm{d}} P=0.07$, CUP versus CUS.

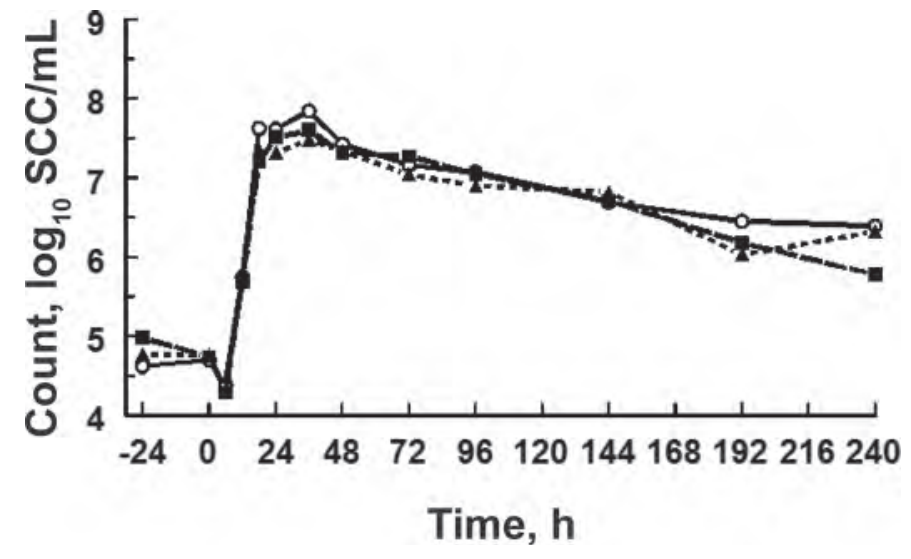

Figure 2. Least squares means SCC $\left(\log _{10}\right.$ cells $\left./ \mathrm{mL}\right)$ in milk after intramammary challenge with Escherichia coli strain 727 at $0 \mathrm{~h}$ in first-lactation heifers with $10 \mathrm{mg} / \mathrm{kg}$ of DM supplemental dietary copper as $\mathrm{Cu}$ sulfate $(\mathbf{\Lambda} ; \mathrm{n}=10)$ or $\mathrm{Cu}$ proteinate $(\boldsymbol{\square} ; \mathrm{n}=9)$ and unsupplemented control heifers $(\mathrm{O} ; \mathrm{n}=9)$. Pooled SEM $=0.20$. Treatment $\times$ time, $P<0.74$.

\section{Clinical Score}

The mean clinical udder score (Figure 3; Trt $\times$ time, $P<0.03$; time, $P<0.0001$; Trt, $P<0.14)$ of the infused quarter was lower $(P=0.03)$ at $12 \mathrm{~h}$ in CUP and CUS heifers compared with CON heifers (1.0, 1.2, and 2.0 respectively). At $96 \mathrm{~h}$, CUS animals tended to have lower scores $(P=0.08)$ compared with CON (2.3 vs. 3.1 , respectively); at 144 h CUP heifers (1.3) had lower $(P=0.01)$ clinical scores compared with CUS or CON heifers, and CUS heifers (1.9) had lower scores compared with CON heifers (2.6). A clinical score of 1.0 was observed $24 \mathrm{~h}$ before and immediately before $E$. coli infusion into one mammary quarter. All groups reached peak clinical score, which did not differ $(P<0.85)$, at $24 \mathrm{~h}$ and then gradually declined for the remaining samples. Clinical udder scores showed that CON animals displayed a clinical response more quickly and maintained an elevated score for a longer period, suggesting that CUS and CUP supplementation modified the clinical response.

\section{Rectal Temperature}

Fever is one of the more obvious signs of the systemic effects of inflammation (Kumar et al., 1997). Peak rectal temperatures were similar between treatments and were about $2^{\circ} \mathrm{C}$ greater than prechallenge temperatures. Rectal temperatures (Figure 4; Trt $\times$ time, $P$ $<0.47$; time, $P<0.0001$; Trt, $P<0.65)$ remained constant from 0 to $12 \mathrm{~h}$ for all treatments and then sharply increased to peak values at $18 \mathrm{~h}$. Temperatures returned to normal by $24 \mathrm{~h}$ in CUS and CON heifers $\left(38.8^{\circ} \mathrm{C}\right.$ each) and were numerically lower than tem- 


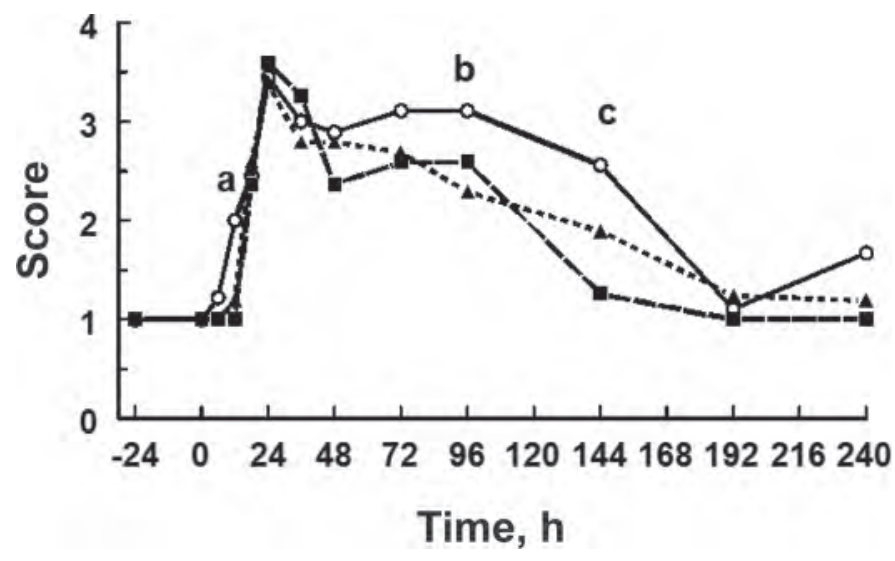

Figure 3. Least squares means clinical udder score after intramammary challenge with Escherichia coli strain 727 at $0 \mathrm{~h}$ in first-lactation heifers with $10 \mathrm{mg} / \mathrm{kg}$ DM supplemental dietary copper as Cu sulfate $(\mathbf{\Delta} ; \mathrm{n}=10)$ or $\mathrm{Cu}$ proteinate $(\mathbf{\square} ; \mathrm{n}=9)$ and unsupplemented control heifers $(O ; \mathrm{n}=9)$. Pooled SEM $=0.3$. Treatment $\times$ time, $P<0.03$ ${ }^{\mathrm{a}} P=0.02$, CUP and CUS versus $\mathrm{CON}$; ${ }^{\mathrm{b}} P<0.08$, CUS versus $\mathrm{CON}$; ${ }^{\mathrm{c}} P<0.01$ CUP versus CUS versus CON.

peratures of CUP heifers $\left(39.3^{\circ} \mathrm{C}\right)$. Temperatures of heifers supplemented with CUP returned to normal by $36 \mathrm{~h}$ and temperatures from all groups were normal for the remaining sample times.

\section{WBC and Hematocrit}

White blood cell count (Figure 5; Trt $\times$ time, $P$ $<0.92$; time, $P<0.0001$; Trt, $P<0.24)$ remained constant for all treatment groups from 0 to $12 \mathrm{~h}$ and then dramatically declined and reached its lowest level at $18 \mathrm{~h}$. The WBC was similar between treatments at $12 \mathrm{~h}\left(7.03,7.03\right.$, and $7.06 \log _{10}$ cells $/ \mathrm{mL}$ for

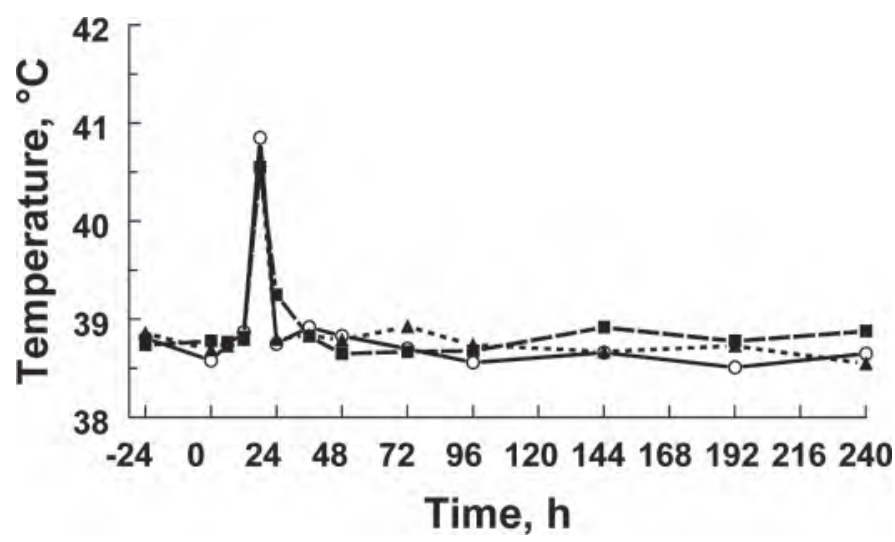

Figure 4. Least squares means rectal temperature $\left({ }^{\circ} \mathrm{C}\right)$ after intramammary challenge with Escherichia coli strain 727 at $0 \mathrm{~h}$ in firstlactation heifers with $10 \mathrm{mg} / \mathrm{kg}$ of DM supplemental dietary copper as $\mathrm{Cu}$ sulfate $(\mathbf{\Lambda} ; \mathrm{n}=10)$ or $\mathrm{Cu}$ proteinate $(\mathbf{\square} ; \mathrm{n}=9)$ and unsupplemented control heifers $(\mathrm{O} ; \mathrm{n}=9)$. Pooled SEM $=0.1$. Treatment $\times$ time, $P<0.47$.
CON, CUS, and CUP groups, respectively) and then declined by about 4.5 million cells $/ \mathrm{ml}(6.83,6.77$, and $6.82 \log _{10}$ cells $/ \mathrm{mL}$ for CON, CUS, and CUP groups, respectively). Depressed WBC continued through 24 $\mathrm{h}$ and then increased sharply for all treatment groups by $36 \mathrm{~h}$. At $36 \mathrm{~h}, \mathrm{WBC}$ returned to preinfusion levels for all groups, with CUP heifers having numerically greater WBC than CUS and CON heifers. Decreased WBC count was also observed by Kremer et al. (1993) after infusion of $E$. coli into one quarter of the mammary gland, although dietary $\mathrm{Cu}$ concentrations were not stated. Migration of WBC from the blood into the udder is thought to be of major importance in host defense against E. coli IMI (Craven and Williams, 1985; Kremer et al., 1993). Leukocytosis is a common feature of inflammatory reactions especially those induced by bacterial infection and results from release of cells from bone marrow (Kumar et al., 1997). Hematocrit did not differ (Trt $\times$ time, $P<0.99$; time, $P<0.004$; Trt, $P<$ 0.74 ) between treatments (ranging from 36.1 to $42.7 \%$ ) and declined over time after intramammary challenge.

\section{Plasma Cu}

Plasma $\mathrm{Cu}$ was similar between treatments (Trt $\times$ time, $P<0.18$; time, $P<0.0001$; Trt, $P<0.61)$ for all times except $24 \mathrm{~h}$ when CUS heifers had numerically greater plasma $\mathrm{Cu}$ concentration compared with CON and CUP heifers (0.87 vs. 0.72 and $0.76 \mu \mathrm{g} / \mathrm{mL}$ for CUS, CON, and CUP heifers, respectively). Least squares means concentrations were constant between treatments $(0.83 \mu \mathrm{g} / \mathrm{mL})$ over the sample period. Our previous work (Scaletti et al., 2003) showed significantly greater plasma $\mathrm{Cu}$ concentrations compared with con-

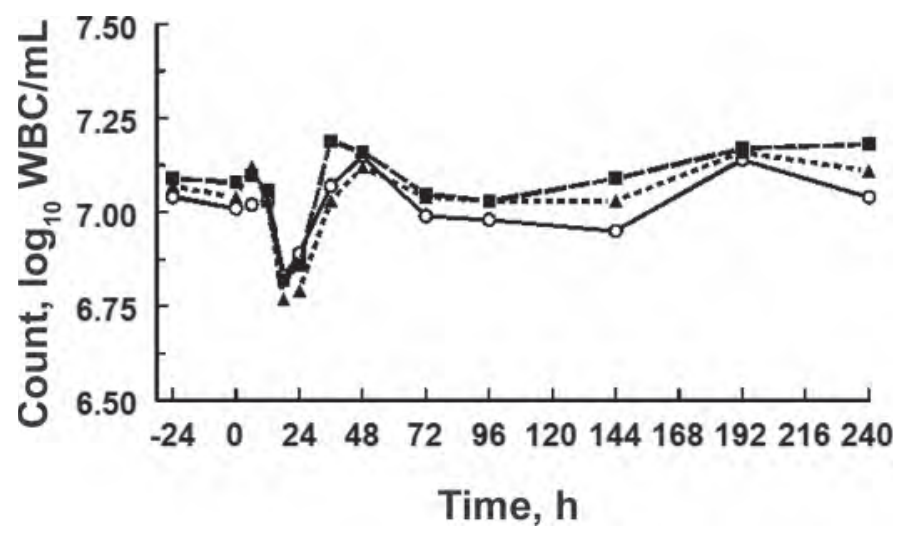

Figure 5. Least squares means white blood cell (WBC) count $\left(\log _{10}\right.$ cells $/ \mathrm{mL}$ ) after intramammary challenge with Escherichia coli strain 727 at $0 \mathrm{~h}$ in first-lactation heifers with $10 \mathrm{mg} / \mathrm{kg}$ of DM supplemental dietary copper as $\mathrm{Cu}$ sulfate $(\mathbf{\Lambda} ; \mathrm{n}=10)$ or $\mathrm{Cu}$ proteinate $(\mathbf{\square} ; \mathrm{n}=9)$ and unsupplemented control heifers $(O ; \mathrm{n}=9)$. Pooled SEM $=0.05$. Treatment $\times$ time, $P<0.92$. 
trols when heifers were supplemented with $\mathrm{Cu}$ sulfate at $20 \mathrm{mg} / \mathrm{kg}$ of DM. Increased plasma $\mathrm{Cu}$ levels during infection and inflammation have also been noted in rats (Conforti et al., 1982; Oliva et al., 1987).

\section{Plasma Cp}

Ceruloplasmin activity after intramammary challenge did not differ between treatments (Trt $\times$ time, $P$ $<0.74$; time, $P<0.0001$; Trt, $P<0.33)$. Overall $\mathrm{Cp}$ activity was $61.2,68.8$, and $64.7 \mathrm{IU} / \mathrm{L}$ for CON, CUS, and CUP heifers, respectively. Copper-supplemented heifers had numerically greater $\mathrm{Cp}$ activities than $\mathrm{CON}$ heifers for several samples. Activity increased from -24 $\mathrm{h}$ to $0 \mathrm{~h}$ and then decreased after challenge with E. coli for all groups until $18 \mathrm{~h}$. Other studies in rats (Conforti et al., 1982) and Holstein steers (Stabel et al., 1993) have shown increased Cp activity during inflammation. Our previous research (Scaletti et al., 2003) when supplementing with $\mathrm{Cu}$ at $20 \mathrm{mg} / \mathrm{kg}$ of DM as $\mathrm{Cu}$ sulfate to Holstein heifers found numerically lower plasma $\mathrm{Cp}$ activity after intramammary challenge. Harmon (1998) reported increased $\mathrm{Cp}$ activity in heifers supplemented (10 mg of $\mathrm{Cu} / \mathrm{kg}$ of $\mathrm{DM}$ ) with $\mathrm{Cu}$ sulfate compared with heifers unsupplemented or supplemented with organic $\mathrm{Cu}$. It appears that effects of supplemental $\mathrm{Cu}$ may vary with amount and form provided.

\section{DMI and Milk Production}

No differences between treatment groups (Trt $\times$ time, $P<0.80$; time, $P<0.0001$; Trt, $P<0.60)$ for percentage DMI (expressed as percentages of means for $7 \mathrm{~d}$ before challenge) were observed during the period after the challenge, similar to results reported by others in dairy heifers and dairy steers (Stabel et al., 1993). As expected, the greatest decrease in percentage of DMI was on the first day postchallenge. Dry matter intake declined by 20 to $32 \%$ on the first day after intramammary challenge. Anorexia is one of the more obvious signs of systemic effects of inflammation (Kumar et al., 1997). By d 2, DMI started to increase and was 9 to $15 \%$ lower than the prechallenge mean. However, treatments did not differ (Trt $\times$ time, $P<0.60)$ at any of the sample times. Dry matter intake recovered to prechallenge intake by $\mathrm{d} 7$ in CON and CUP heifers and by $\mathrm{d} 9$ in CUS heifers.

Milk production (Figure 6; Trt $\times$ time, $P<0.05$; time, $P<0.0001$; Trt, $P<0.16)$ declined $1 \mathrm{~d}$ after challenge for CON and CUS heifers, whereas CUP heifers maintained milk production levels after intramammary challenge (94.4 and 95.8 vs. $100.7 \%$, for CON, CUS, and CUP, respectively), although this difference in production was not significant $(P=0.58)$. Milk pro- duction continued to decrease until d 2 when all groups reached their lowest milk production $(71.0,73.6$, and $80.9 \%$ for CON, CUS, and CUP, respectively). By d 3 , milk production tended to be greater $(P=0.06)$ for CUP heifers compared with CON and CUS heifers (101.3 vs. 90.0 and $86.7 \%$, respectively). Differences in milk production were also observed on d 4 when CUP and CON heifers had greater $(P=0.05)$ milk yield than CUS heifers (103.5 and 99.1 vs. 89.0\%, respectively). Heifers in the CUP group tended to have greater milk production $(P=0.09)$ than CUS heifers on $\mathrm{d} 5$. Production was similar between treatments from d 6 until d 10 when CUP heifers tended to have greater $(P=$ 0.06 ) milk yield than CON and CUS heifers (112.4 vs. 99.3 and $99.7 \%$, respectively). Milk yield was similar between treatments for the remaining samples after the intramammary challenge. Differences in milk production were observed although DMI did not differ.

\section{Comparison with a Previous Challenge Study}

Few challenge studies in lactating dairy cattle have evaluated the effects of organic and inorganic forms of supplemental $\mathrm{Cu}$ on mastitis. Results after intramammary challenge with $E$. coli in the present study differ somewhat from results of our previous study (Scaletti et al., 2003), when Holstein heifers were supplemented at a greater rate $(20 \mathrm{mg}$ of $\mathrm{Cu} / \mathrm{kg}$ of $\mathrm{DM})$ with $\mathrm{Cu}$ sulfate. Inorganic $\mathrm{Cu}$ supplementation at $20 \mathrm{mg} / \mathrm{kg}$ of

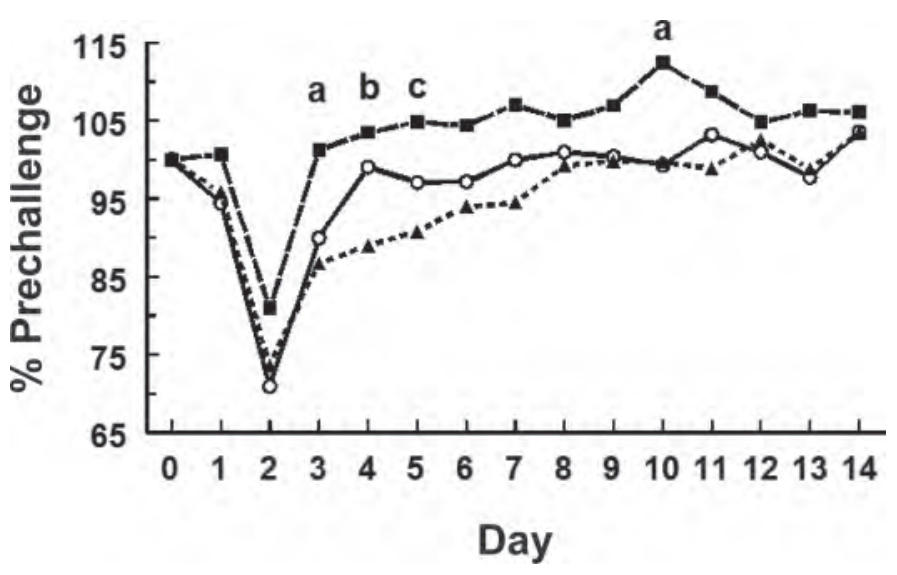

Figure 6. Least squares means daily milk yield after intramammary challenge with Escherichia coli strain 727 at $0 \mathrm{~h}$ in first-lactation heifers with $10 \mathrm{mg} / \mathrm{kg}$ of DM supplemental dietary copper as $\mathrm{Cu}$ sulfate $(\boldsymbol{\Lambda} ; \mathrm{n}=10 ; 31.4 \mathrm{~kg}$ average 7 -d milk yield) or $\mathrm{Cu}$ proteinate $(\boldsymbol{\square}$ $\mathrm{n}=9 ; 30.8 \mathrm{~kg}$ average 7 -d milk yield) and unsupplemented control heifers $(O ; \mathrm{n}=9 ; 32.0 \mathrm{~kg}$ average 7 -d milk yield). Data are expressed as percentages of means for $7 \mathrm{~d}$ before challenge following the formula used by Hogan et al. (1995): [(b/a) × 100], where $\mathrm{a}=$ mean value for $7 \mathrm{~d}$ before challenge, and $\mathrm{b}=$ daily value postchallenge. Pooled SEM $=4.3$. Treatment $\times$ time, $P<0.05 .{ }^{\mathrm{a}} P<0.06 \mathrm{CUP}$ versus $\mathrm{CON}$ and CUS; ${ }^{\mathrm{b}} \mathrm{P}<0.05 \mathrm{CUP}$ versus CUS and CUS versus $\mathrm{CON} ;{ }^{\mathrm{c}} P<0.09$ CUP versus CUS. 
DM resulted in lower peak bacterial counts, lower SCC, lower clinical udder scores, and lower peak rectal temperatures compared with responses in unsupplemented control animals. Liver $\mathrm{Cu}$ values were similar among $\mathrm{Cu}$-supplemented heifers in both trials regardless of $\mathrm{Cu}$ source or level. Another drawback in making comparisons between the present study and our previous work (Scaletti et al., 2003) is the difference in $\mathrm{Cu}$ status of the control animals in each study. Control heifers in the present study had liver $\mathrm{Cu}$ concentrations averaging 65 $\mathrm{mg} / \mathrm{kg}$ of DM, whereas control heifers in the previous study averaged $40 \mathrm{mg} / \mathrm{kg}$ of DM over the 110-d supplementation period. The concentration at which liver $\mathrm{Cu}$ is considered clinically deficient varies between reports in the literature. Mills (1987) reported that when liver $\mathrm{Cu}$ concentrations fell below $30 \mathrm{mg} / \mathrm{kg}$ of DM, normal plasma $\mathrm{Cu}$ could not be maintained and $\mathrm{Cp}$ activity (Cu-dependent) may be lost. Tiffany et al. (2002) stated that liver $\mathrm{Cu}$ concentrations under $25 \mathrm{mg} / \mathrm{kg}$ of DM indicated severe deficiency, which is in agreement with Underwood and Suttle (2001). Puls (1994) reported liver $\mathrm{Cu}$ concentrations of 2.0 to $35 \mathrm{mg} / \mathrm{kg}$ of $\mathrm{DM}$ as deficient and those from 17.5 to $87.5 \mathrm{mg} / \mathrm{kg}$ of $\mathrm{DM}$ as marginal based on diagnostic data. According to Tiffany et al. (2002), Cu liver concentrations below $75 \mathrm{mg} / \mathrm{kg}$ of DM may indicate onset of deficiency. However, the $\mathrm{Cu}$ concentration necessary for optimal host defense is not clear (Wikse et al., 1992; Puls, 1994).

\section{CONCLUSIONS}

Both $\mathrm{Cu}$ sulfate and $\mathrm{Cu}$ proteinate supplemented at $10 \mathrm{mg}$ of $\mathrm{Cu} / \mathrm{kg}$ of $\mathrm{DM}$ were equally able to return marginally $\mathrm{Cu}$-deficient Holstein heifers to $\mathrm{Cu}$-adequate status after $40 \mathrm{~d}$ of supplementation. Responses of heifers to $E$. coli challenge were moderately influenced by supplemental $\mathrm{Cu}$ at $10 \mathrm{mg} / \mathrm{kg}$ of DM. Copper supplementation did not lower peak responses after intramammary challenge although benefits were observed for $\mathrm{Cu}$ supplementation. Supplementation with CUP was associated with improvements in milk yield, clinical udder score, and E. coli numbers compared with CON and CUS treatments. This study is the first to investigate effects of organic $\mathrm{Cu}$ supplementation on experimentally induced mastitis in dairy cattle compared with an inorganic source. Continued investigation is warranted concerning the appropriate level of $\mathrm{Cu}$ supplementation.

\section{ACKNOWLEDGMENTS}

The authors thank J. S. Hogan (Department of Animal Sciences, The Ohio State University, Columbus) for providing Escherichia coli strain 727 for the intra- mammary challenge. The authors also thank Alltech Inc. (Nicholasville, $\mathrm{KY}$ ) for providing Bioplex $\mathrm{Cu}$.

\section{REFERENCES}

Anderson, R., R. Collier, A. Guidry, C. Heald, R. Jenness, B. Larson, and H. Tucker. 1985. Mastitis and the immune system of the mammary gland. Pages 229-262 in Lactation. B. Larson, ed. The Iowa State University Press, Ames.

Boyne, R., and J. Arthur. 1981. Effects of selenium and copper deficiency on neutrophil function in cattle. J. Comp. Pathol. 91:271276.

Ceballos-Marquez, A., H. Barkema, H. Stryhn, J. Wichtel, J. Neumann, A. Mella, J. Kruse, M. Espindola, and F. Wittwer. 2010. The effect of selenium supplementation before calving on earlylactation udder health in pastured dairy heifers. J. Dairy Sci. 93:4602-4612.

Conforti, A., L. Franco, R. Milanino, and G. Velo. 1982. Copper and ceruloplasmin $(\mathrm{Cp})$ concentrations during the acute inflammatory process in rats. Agents Actions 12:303-307.

Cope, C., A. Mackenzie, D. Wilde, and L. Sinclair. 2009. Effects of level and form of dietary zinc on dairy cow performance and health. J. Dairy Sci. 92:2128-2135.

Craven, N., and M. Williams. 1985. Defenses of the bovine mammary gland against infection and prospects for their enhancement. Vet. Immunol. Immunopathol. 10:71-127.

Erskine, R. 1993. Nutrition and Mastitis. The Veterinary Clinics of North America: Food Animal Practice. K. Andersen, ed. W. B. Saunders, Philadelphia, PA.

Erwin, E., I. Dyer, T. Meyer, and K. Scott. 1956. Uses of aspiration biopsy technique. J. Anim. Sci. 15:428-434.

Federation of Animal Science Societies. 1999. Guide for the Care and Use of Agricultural Animals in Research and Teaching. 1st rev. ed. Federation of Animal Science Societies, Champaign, IL.

Harmon, R. 1998. Trace minerals and dairy cattle: Importance for udder health. Pages 485-495 in Biotechnology in the Feed Industry. T. Lyons and K. Jacques, ed. Nottingham University Press, Lexington, KY.

Harmon, R. J., T. W. Clark, D. S. Trammell, B. A. Smith, P. M. Torre, and R. W. Hemken. 1994. Influence of copper status in heifers on response to intramammary challenge with Escherichia coli endotoxin. J. Dairy Sci. 77(Suppl. 1):198. (Abstr.)

Harmon, R., R. Eberhart, D. Jasper, B. Langlois, and R. Wilson. 1990. Microbiological procedures for the diagnosis of bovine udder infection. National Mastitis Council, Arlington, VA.

Harmon, R., and P. Torre. 1997. Economic implications of copper and zinc proteinates: Role in mastitis control. Page 419 in Biotechnology in the Feed Industry. T. Lyons and K. Jacques, ed. Nottingham University Press, Nottingham, UK.

Hogan, J., W. Weiss, K. Smith, D. Todhunter, and D. Schoenberger. 1995. Effects of an Escherichia coli J5 vaccine on mild clinical coliform masitis. J. Dairy Sci. 78:285-290.

Jones, D., and N. Suttle. 1981. Some effects of copper deficiency on leucocyte function in sheep and cattle. Res. Vet. Sci. 31:151-156.

Knowles, S., N. Grace, K. Wurms, and J. Lee. 1999. Significance of amount and form of dietary selenium on blood, milk and casein selenium concentrations in grazing cows. J. Dairy Sci. 82:429-437.

Kremer, W., E. Noordhuizen-Stassen, F. Grommers, A. Daemen, and A. Brand. 1993. Blood polymorphonuclear leukocyte chemotaxis during experimental Escherichia coli bovine mastitis. J. Dairy Sci. 76:2613-2618.

Kumar, V., R. Cotran, and S. Robbins. 1997. Disorders of the immune system. Pages 300-304 in Pathologic Basis of Disease. R. Cotran and S. Robbins, ed. W. B. Saunders, Philadelphia, PA.

Malbe, M., E. Klaassen, L. Kaartinen, M. Attila, and F. Atroshi. 2003. Effects of oral selenium supplementation on mastitis markers and pathogens in Estonian cows. Vet. Ther. 4:145-154.

Malbe, M., M. Klaassen, W. Fang, V. Myllys, M. Vikerpuur, K. Nyholm, S. Sankari, K. Suoranta, and M. Sandholm. 1995. Comparisons of selenite and selenium yeast feed supplements on Se- 
incorporation, mastitis and leucocyte function in Se-deficient dairy cows. Zentralbl. Veterinarmed. A 42:111-121.

Mills, C. 1987. Biochemical and physiological indicators of mineral status in animals: Copper, cobalt, and zinc. J. Anim. Sci. 65:17021711.

NRC. 1989. Nutrient Requirements of Dairy Cattle. 6th rev. ed. National Academy of Sciences, Washington, DC.

Oliva, J. C., M. Castell, J. Queralt, and C. Cstelotte. 1987. Effect of chronic inflammation on copper and zinc metabolism. Rev. Esp. Fisiol. 43:25-31.

Ortman, K., and B. Pehrson. 1999. Effect of selenate as a feed supplement to dairy cows in comparison to selenite and selenium yeast. J. Anim. Sci. 77:3365-3370.

Puls, R. 1994. Mineral Levels in Animal Health. 2nd ed. Sherpa International, Clearbrook, Canada.

SAS Institute. 1985. SAS User's Guide: Statistics. SAS Institute Inc., Cary, NC.

Scaletti, R., D. Trammell, B. Smith, and R. Harmon. 2003. Role of dietary copper in enhancing resistance to Escherichia coli mastitis. J. Dairy Sci. 86:1240-1249.

Schosinsky, K., H. Lehman, and M. Beeler. 1974. Measurement of ceruloplasmin from its oxidase activity in serum by use of o-dianisidine dihydrochloride. Clin. Chem. 20:1556-1563.

Smith, K., J. Harrison, D. Hancock, D. Todhunter, and H. Conrad. 1984. Effect of vitamin $\mathrm{E}$ and selenium supplementation on incidence of clinical mastitis and duration of clinical symptoms. J. Dairy Sci. 67:1293-1300.
Smith, K., J. Hogan, and W. Weiss. 1997. Dietary vitamin E and selenium affect mastitis and milk quality. J. Anim. Sci. 75:1659-1665.

Sox, H., Jr., and M. Liang. 1986. The erythrocyte sedimentation rate. Ann. Intern. Med. 104:515-523.

Stabel, J., J. Spears, and T. Brown Jr. 1993. Effect of copper deficiency on tissue, blood characteristics, and immune function of calves challenged with infectious bovine rhinotracheitis virus and Pasturella hemolytica. J. Amim. Sci. 71:1247-1255.

Tiffany, M., L. McDowell, G. O'Connor, F. Martin, N. Wilkinson, S. Percival, and P. Rabiansky. 2002. Effects of residual and reapplied biosolids on performance and mineral status of grazing beef steers. J. Anim. Sci. 80:260-269.

Torre, P., R. Hemken, R. Harmon, R. Hemken, T. Clark, D. Trammell, and B. Smith. 1996. Mild dietary copper insufficiency depresses blood neutrophil function in dairy cattle. J. Nutr. Immunol $4: 3-24$.

Underwood, E., and N. Suttle. 2001. The Mineral Nutrition of Livestock. CAB International Publishing, Wallingford, UK.

Wikse, S., D. Herd, R. Field, and P. Holland. 1992. Diagnosis of copper deficiency in cattle. J. Am. Vet. Med. Assoc. 200:1625-1629.

Wright, C., and J. Spears. 2001. Effects of zinc source and dietary level on zinc metabolism in Holstein bull calves. J. Anim. Sci. 79(Suppl. 1):86. (Abstr.)

Xin, Z., R. Hemken, D. Waterman, and R. Harmon. 1991. Effects of copper status on neutrophil function, superoxide dismutase, and copper distribution in steers. J. Dairy Sci. 74:3078-3085. 